\title{
UPAYA SOSIALISASI \\ TINGGALAN BUDAYA MASA LAMPAU DI MALUKU
}

\author{
G.M. Sudarmika ${ }^{1}$
}

\section{Pendahuluan}

Upaya meningkatkan harkat dan martabat bangsa dalam menyongsong era globalisasi informasi dan komunikasi, ilmu arkeologi semakin dirasakan peranan dan manfaatnya. Hal ini didukung oleh bidang garapan dari ilmu arkeologi itu sendiri yaitu berupa penelitan terhadap tinggalan budaya fisik manusia masa lampau dalam upaya mempelajari kehidupan atau tingkah laku manusia dari pendukung tinggalan budaya tersebut. Hasil dari penelitian tersebut nantinya diharapkan dapat digunakan sebagai pedoman di masa sekarang dan proyeksi ke masa yang akan datang. Harapan ini didukung sepenuhnya oleh TAP MPR No. II/MPR/1988 tentang GBHN yang menegaskan bahwa kebudayaan Indonesia yang mencerminkan nilai-nilai luhur bangsa harus dipelihara, dibina dan dikembangkan guna memperkuat penghayatan dan pengamalan Pancasila, miningkatkan kualitas hidup, memperkuat kepribadian bangsa, mempertebal rasa harga diri dan kebangggaan nasional, memperkooh jiwa persatuan dan kesatuan bangsa serta mampu menjadi penggerak bagi perwujudan cita-cita bangsa di masa depan.

Pengetahuan tentang unsur kebudayaan masa lampau yang megah dan agung akan dapat meningkatkan pula kebanggaan bangsa yang bersangkutan sebagai pewaris dari budaya itu sendiri, selain itupula identitas suatu bangsa biasanya juga dikaitkan dengan keagungan masa lampau. Untuk itu penelitian-penelitian arkeologis di seluruh Nusantara perlu ditingkatkan baik kuantitas maupun kualitasnya.

Maluku merupakan salah satu bagian dari wilayah Nusantara yang berbentuk kepulauan menyimpan tinggalan arkeologi cukup banyak dan menarik.

1 Kasubag Tata Usaha/Peneliti Balai Arkeologi Ambon 
Wilayah kepulauan Maluku sebagian besar terdiri atas laut, luas daratan sekitar $85.728 \mathrm{Km} 2$ yang tersebar pada perairan seluas 765.272 $\mathrm{Km} 2$, sehingga perbandingan luas daratan dan lautan adalah $1: 9$.

Secara astronomi wilayah kepulauan Maluku terletak di antara 30 lintang utara dan 80-30 lintang selatan, serta di antara $1240 \mathrm{~s} / \mathrm{d}$ 1330 bujur timur. Daratan Maluku terdiri dari hampir 1000 buah pulau besar dan kecil, serta sebagian besar daratannya terdiri dari hutan tropis. Perairan wilayah Maluku yang merupakan 8/9 dari luas propinsi Maluku terdiri dari laut-laut yang dalam seperti Laut Banda, dengan titik terdalam di perairan Nusantara, sedangkan laut dalamnya adalah laut Arafuru yang menutupi lautan kontinental (Uniputty, T.J.A, 1993)

Melihat kondisi geografis yang terdiri dari hampir seribu buah pulau tersebut, tentunya akan memunculkan atau melahirkan corak budaya yang beraneka ragam. Selama ini tinggalan budaya masa lampau di Maluku belum banyak diteliti dan dipublikasikan atau di sosialisasikan (khususnya tinggalan budaya fisik), sehingga anggapan selama ini terhadap hasil budaya hanyalah berupa taria-tarian, bernyanyi atau tarik suara yang seakan-akan kebudayaan itu hanyalah kesenian saja.Tinggalan budaya masa lampau yang belum banyak dipahami oleh masyarakat Maluku adalah tinggalan budaya yang bersifat bendawi baik yang berasal dari jaman prasejarah, Islam dan kolonial. Tinggalan budaya tersebut sekarang tersebar hampir di semua pulau yang ada di Maluku. Secara periodisasi tinggalan budaya masa lampau yang merupakan hasil penelitian arkeologi selama ini tidak selengkap tinggalantinggalan yang ada di pulau Jawa. Tinggalan budaya yang belum ditemukan sampai sekarang adalah tinggalan budaya dari jaman klasik.

Tinggalan budaya masa lampau yang paling menonjol ditemukan di Maluku adalah hasil budaya dari masa prasejarah di antaranya berupa menhir, dolmen (meja batu) sedangkan masa kolonial Belanda yaitu berupa benteng. Tinggalan Benteng ditemukan hampir di setiap pulau di Maluku baik yang masih dalam keadaan utuh, rusak dan hanya pondasinya saja. Tinggalan lainnya berupa tinggalan dari jaman Islam yaitu berupa mesjid, naskah, makam, keraton dan lain sebagainya. Selain itu pula pemahaman atau pengertian dari masyarakat terhadap tinggalan budaya masa lampau masih kurang. Hal ini terlihat pada beberapa penelitian di lapangan dijumpai yaitu adanya material-meterial bangunan benteng sering dimanfaatkan untuk membangun rumah, bangunan dolmen yang dibuang atau dihancurkan karena sudah tidak sesuai dengan budaya dan kepercayaan mereka, dan kurang adanya tanggung jawab terhadap pemeliharaan bangunan-bangunan bersejarah lainnya (terutama yang belum dipugar).

\section{Tinggalan Budaya Masa Lampau}

Dalam Undang-Undang No. 5 tahun 1995 tentang Benda Cagar Budaya di jelaskan bahwa Benda Cagar Budaya adalah semua benda buatan manusia, bergerak atau tidak bergerak yang berupa kesatuan atau kelompok, atau bagian-bagiannya atau sisa-sisanya, yang berumur sekurang-kurangnya 50 (lima puluh) tahun, atau mewakili masa gaya sekurang-kurangnya 50 (lima puluh) tahun, serta dianggap mempunyai nilai penting bagi sejarah, ilmu pengetahuan, dan kebudayaan. Pengertian terhadap tinggalan budaya masa lampau yang dibahas dalam makalah ini akan mengacu pada pengertian dari benda cagar budaya seperti tersebut di atas. Sedangkan kebudayaan kalau ditinjau dari sudut pengertiannya adalah merupakan seluruh sistem gagasan dan tindakan, serta karya yang dihasilkan manusia dalam kehidupan bermasyarakat yang dijadikan miliknya dengan belajar (Koentjaraningrat, 1996).

Ditinjau dari wujudnya, kebudayaan itu terdiri dari; (1) artefak atau benda-benda fisik (2) tingkah laku atau tindakan yang berpola dan (3) gagasan yang idealogis. Wujud kebudayaan yang pertama adalah semua hasil budaya yang sifatnya konkrit, dapat diraba dan difoto, misalnya candi, gereja, benteng masjid dan lain sebagainya. Sebutan dari wujud budaya ini adalah kebudayaan fisik. Wujud kebudayaan yang kedua masih bersifat konkrit misalnya menari, berbicara, mencangkul menyanyi dan lain sebagainya. Semua tingkah laku tersebut dilakukan dari hari kehari, dari masa kemasa yang merupakan tingkah laku yang berdasarkan sistem, sehingga tingkah laku tersebut disebut sistem sosial. Wujud kebudayaan yang ketiga adalah berupa gagasan tempatnya ada pada kepala setiap individu yang bersangkutan, wujud kebudayaan seperti ini bentuknya sangat abstrak yang disebut dengan sistem budaya. Wujud kebudayaan yang keempat adalah berupa gagasan yang 
idealogis, yaitu merupakan gagasan yang telah dipelajari oleh para warga sejak usia dini yang dapat menetukan sifat corak dari fikiran atau cara berfikir, serta tingkah laku manusia. Wujud dari kebudayaan ini dikenal dengan istilah nilai budaya (Koentjaraningkat, 1996).

Di bagian atas telah disinggung bahwa hasil kebudayaan fisik masa lampau yang ada di daerah Maluku cukup banyak dan tersebar dihampir semua pulau yang ada di Maluku. Penelitian yang telah dilakukan selama ini baik sebelum maupun sesudah berdirinya Balai Arkeologi Ambon berhasil menampilkan atau memberi gambaran tentang potensi tinggalan budaya masa lampau di Maluku yang terdiri dari ; (1) jaman Prasejarah, (2) jaman Islam, dan (3) jaman Kolonial, sedangkan jaman Klasik sampai saat sekarang datanya belum ditemukan dalam lingkup kajian ilmiah. Tinggalan budaya yang belum banyak didata adalah tinggalan yang berasal dari jaman prasejarah, sedangkan tinggalan lainnya yang berasal dari masa sesudahnya sudah cukup banyak mendapat perhatian baik formal maupun informal. Hal ini terbukti dari beberapa tinggalan budaya dari jaman Islam dan kolonial telah banyak dipugar di antaranya masjid, keraton, makam, benteng dan gereja.

\section{Sosialisasi Tinggalan Budaya Masa Lampau 3.1 Penelitian Arkeologi}

Salah satu upaya yang dapat dilakukan untuk dapat mengetahui dan memahami tinggalan budaya manusia masa lampau adalah dengan mengadakanpenelitianarkeologi.Penelitiandalamduniaarkeologiadalah berupa pengumpulan data tinggalan arkeologi sebanyak-banyaknya yang ada di lapangan baik melalui survey maupun ekskavasi yang kemudian dilanjutkandengananalisis dan interpretasi.Penemuanterhadaptinggalan budaya masa lampau adalah merupakan sasaran utama dari setiap penelitian arkeologi, maka dimanapun adanya indikasi dari tinggalan budaya tersebut akan dicari dan diusahakan untuk menemukannya.

Survey dalam ilmu arkeologi adalah berupa penyelidikan dan pengamatan secara mendalam terhadap suatu masalah. Survey dalam pengertian ini adalah pengumpulan data arkeologi sebanyakbanyaknya untuk dapat memahami kegiatan manusia pada masa lampau melalui gejala-gejala arkeologis. Survey dapat pula berarti melacak kebenaran berita tentang data dalam literatur atau melacak berita dalam laporan temuan. Survey merupakan teknik pengumpulan data secara horizontal, yaitu mengumpulkan tinggalan arkeologi yang ada di atas permukaan tanah baik berupa artefak maupun non-artefak. Metode survey juga menggunakan teknik wawancara yaitu mengorek data melalui informasi dari beberapa tokoh masyarakat yang dianggap mengetahui tentang seluk beluk tinggalan arkeologi yang sedang diteliti. Kegiatan survey juga diikuti dengan deskripsi, perekaman dan analisis.

Penelitian selain survey (horizontal) juga dilakukan dengan ekskavasi (vertikal) atau penggalian. Ekskavasi adalah suatu usaha untuk memperoleh benda arkeologi dalam keadaan insitu, sehingga dapat disimpulkan lebih jelas aspek-aspek bentuk, ruang dan waktu, termasuk konteks, fungsi serta struktur benda, dan tingkah laku pendukungnya. Kegiatan ekskavasi merupakan mata rantai antara discovery (penemuan) dan interpretasi yang pelaksanaannya cendrung didahului dengan survey. Ekskavasi merupakan metode penjaringan data atau informasi arkeologis pada obyek-obyek yang ada di bawah tanah dengan cara menggali secara sistematis dan terkendali. Melalui ekskavasi dapat ditemui data yang ideal untuk menjaring data yang lengkap dimensinya. Karena selain menampilkan dimensi bentuk, juga dilengkapi dengan dimensi ruang dan waktu.

Kelengkapan data yang dijaring itu sangat diperlukan karena berhubungan langsung dengan interpretasi arkeologis yang akan disusun atau dihasilkan. Mengingat sumber daya arkeologis sangat terbatas, tidak bisa diperbaiki, kontekstual dan sulit dideteksi, sehingga ekskavasi harus dilakukan sebaik dan secermat mungkin yang diikuti dengan laporan yang lengkap. Kegiatan analisis dan interpretasi sangat penting untuk dilakukan, karena semua hal yang berkenaan dari tinggalan budaya tersebut akan dikenali baik bentuk, umur, persebaran, fungsi serta peranannya bagi kehidupan masyarakat masa lampau. Kajian terhadap fungsi dan peranan dari suatu tinggalan budaya masa lampau akan mengacu pada pengertian/pemahaman terhadap nilai dari suatu tinggalan budaya. Pengertian atau pemahaman terhadap nilai budaya yang terkandung di dalamnya akan dapat 
memberikan pengetahuan terhadap tindakan yang akan dilakukan oleh pewaris dari suatu tinggalan budaya masa lampau tersebut.

Penelitian arkeologi di wilayah operasional Balai Arkeologi Ambon (wilayah Provinsi Maluku), yang merupakan bagian integral dari pengembangan penelitian arkeologi nasional, pada dasarnya harus dapat menjabarkan tujuan penelitian arkeologidemikepentingan pembangunan nasionalkhususnyabidangarkeologidandilain pihak dapatmemanfaatkan secara optimal semua potensi sumberdaya arkeologi di daerah demi kepentingan pembangunan dengan mengatasi segala kendala yang ada.

Pelaksanaan penelitian di Maluku (termasuk oleh peneliti asing), telah berlangsung sejak tahun 70 an, atau Pelita II, hingga sekarang telah menunjukkan minat dan perkembangan yang cukup berarti. Perkembangan ini akan terus berlanjut sejalan dengan eksistensi Balai Arkeologi dan minat peneliti asing. Kenyataan menunjukkan bahwa publikasi hasil-hasil penelitian yang kita jumpai sekarang, diterbitkan oleh peneliti-peneliti atau lembaga-lembaga asing. Permasalahan yang dirasakan sesuai dengan gejalayang diamati telah terjadiketidakmerataan dalam penentuan sasaran penelitian, baik secara kronologis (berdasarkan waktu atau periodisasi), maupun cara pemilihan lokasi/tempat penelitian pada suatu daerah atau pulau. Untuk mengantisipasi hal-hal tersebut di atas maka diperlukan arah kebijakan yang memadai sebagai dasar untuk penyusunan setiap rencana dan program penelitian di Maluku. Teknik pengumpulan data pada umumnya survei permukaan tanah. Tujuan penelitian adalah eksplorasi, yaitu menjajagi data arkeologi yang ada di suatu tempat, serta melampiaskan keingintahuan terhadap sesuatu tinggalan arkeologi. Hal tersebut dilakukan dalam rangka memperoleh data dan informasi arkeologi sebagai bahan pertimbangan penentuan penelitian lebih lanjut dalam bentuk ekskavasi. Hasil-hasil penelitian tersebut diharapkan dapat memberikan gambaran umum tingkat-tingkat budaya di Maluku, yaitu prasejarah, Islam, dan Kolonial dan Klasik. Untuk lebih jelasnya tentang kepurbakalaan yang telah diteliti selama ini sesuai dengan periodisasinya adalah sebagai berikut :

\subsubsection{Tinggalan Tradisi Budaya Prasejarah}

Jaman prasejarah di Maluku ditandai dengan ditemukannya lukisan-lukisan prasejarah pada dinding-dinding batu karang atau gua. Penelitian terhadap lukisan-lukisan prasejarah diawali dari penelitiannya J. Roder di Desa Rumasokat, Kecamatan Wahai, Maluku Tengah. Roder menemukan sejumlah lukisan yang terdapat pada dinding batu karang yang terjal. Lukisan tersebut menggunakan warna merah dalam berbagai bentuk/motif, di antaranya adalah berupa cap tangan, matahari, topeng, perahu, motif ikan dan lain sebagainya. Penelitian Roder ini merupakan langkah awal dari penelitian bidang prasejarah di Maluku. Penelitian terhadap lukisanlukisan prasejarah terus dilakukan, sehingga ditemukan sejumlah data baru di antaranya adalah lukisan-lukisan yang ditemukan di Desa Batutulis, Kecamatan Buru Selatan, Maluku Tengah yaitu pada sebuah dinding batu karang yang terjal. Adapun bentuk dari lukisan tersebut antara lain berupa ikan, matahari, cap tangan, dan lain sebagainya.

Lukisan prasejarah yang selama ini dianggap cukup bervariasi adalah lukisan yang ditemukan pada dinding gua di Desa Ohoidertawun, Kecamatan Kei Kecil, Maluku Tenggara. Situs ini terdiri dari empat buah gua prasejarah, dan kempat gua tersebut mengandung lukisanlukisan prasejarah berupa telapak tangan, manusia dalam posisi menari, berkelahi, duduk, topeng manusia dan gambar matahari.

Tinggalan budaya prasejarah selain berupa lukisan seperti yang telah disebutkan di atas, juga ditemukan tinggalan-tinggalan budaya lainnya yaitu tradisi megalitik berupa dolmen atau meja batu. Dolmen banyak ditemukan di wilayah Maluku, di beberapa daerah di Maluku dolmen masih memainkan peranannya sebagai sarana pelengkap upacara. Bahkan dalam perkembangannya dolmen di Maluku mempunyai fungsi yang lebih kompleks. Adapun beberapa fungsi yang berkembang di Maluku dalam upaya pemanfaatan tinggalan dolmen di antaranya adalah sebagai batas wilayah pekarangan (mata rumah), tempat pelaksanaan upacara kakehan (upacara pendewasaan anak), batu sumpah (menyumpah para pejabat desa) dan sebagai tempat untuk melaksanakan upacara pela (upacara persekutuan). Di beberapa tempat di Maluku ditinjau dari keletakannya, yaitu antara dolmen dan baeliu (balai pertemuan) akan dapat memberikan 
penjelasan atau pengertian mengenai asal-usul dari suatu kelompok masyarakat yaitu apakah masyarakat tersebut berasal dari kelompok pata siwa atau pata lima. (kelompok pata siwa kedudukannya di masyarakat lebih tinggi dibandingkan dengan pata siwa).

Penelitian yang telah dilaksanakan selama ini menampilkan sejumlah tinggalan dolmen seperti misalnya dolmen yang ditemukan di Desa Amahusu, Kaibobo, Oma, Eti, Tuhaha dan tempat-tempat lainnya. sebagian besartemuandolmen diMaluku dijumpai dirumah-rumahataudi kebun-kebun penduduk baik pada dataran tinggi maupun dataran rendah.

\subsubsection{Tinggalan Budaya Islam}

Tinggalan budaya Islam yang berhasil di data selama ini adalah berupa masjid, kedaton dan makam. Tinggalan masjid di Maluku jumlahnya cukup banyak misalnya; Mesjid Raya Al Jami di Desa Kao, Mesjid Hatuhahamarima di Desa Rohomoni, Mesjid Wapane di Desa Hila, dan Mesjid Ternate yang didirikan oleh Sultan Zainal Abidin Syah (1486-1500) kemudian pembangunannya dilanjutkan oleh Sultan Hamzah yang memerintah pada tahun 1627 - 1648.

Tinggalan kedaton yang berhasil di data berjumlah dua buah, yaitu kedaton Ternate dan Tidore. Kedaton Ternate sesuai dengan sejarahnya telah tiga kali mengalami perpindahan. Beberapa pendiri dari kedaton adalah Sultan Baab Mansyur Malamo pada tahun 1257 yang berlokasi di Desa Foramdiahi, kemudian Sultan Saidi Barakati (1606 - 1610) yang berlokasi di Desa Kasturian, dan yang terakhir Sultan yeng ke - 40 yaitu Sultan Muhammad Ali (1788-1814). Pembangunan kedaton yang terakhir ini berlokasi di Desa Soa Sio, dan sejak tahun 1987 sampai dengan sekarang kedaton ini telah difungsikan sebagai museum dengan nama Museum Memorial Kedaton Ternate.

Kedaton Tidore terletak di Pulau Tidore didirikan oleh Sultan Mutttahidin Muhammad Taher pada tahun 1812 - 1861 dengan nama Kedaton Kei. Setelah adanya perang saudara dan gempa bumi yang cukup dahsyat, kedoton ini mengalami rusak berat dan sekarang hanya tinggal pondasinya saja. Mengenai tinggalan makam cukup banyak ditemukan di Maluku, di antaranya adalah beberapa makam Sultan Ternate yaitu ; makam Sultan Hamzah (1627 -
1648), makam Muhammad Ali (1788 - 1814), makam Muhammad Arzad (1850 - 1875), dan makam Ayahar Syah (1875 - 1902).

\subsubsection{Tinggalan Budaya Kolonial}

Kolonisasi bangsa asing khususnya bangsa Belanda di Maluku berlangsung cukup lama dan kerjasama diantara kedua belah pihak juga cukup baik. Hal ini dapat dirasakan dari data-data arkeologisnya khususnya tinggalan benteng. Selama penelitian yang telah dilakukan terhadap budaya fisik jaman kolonial tinggalan benteng cukup banyak ditemukan hampir disetiap pulau yang ada di Maluku. Bentengbenteng yang telah diteliti atau disurvey oleh Balai Arkeologi Ambon di antaranya adalah benteng Toluko, Orange, Kalamata di Ternate, benteng Horn di Desa Pelauw dan benteng New Zelandia di Desa Haruku. Tinggalan-tingalan benteng tersebut sekarang kondisinya ada yang masih baik ada pula yang sudah rusak bahkan hanya tinggal pondasinya saja, dan ada pula yang sudah dipugar. Selain bangunan benteng, tinggalan masa kolonial lainnya adalah berupa bangunan Perk dan Gereja. Perk merupakan tempat atau rumah yang dibangun khusus untuk para pekerja/pengelola kebun pala. Tinggalan Perk ini lebih banyak terkonsentrasi di Kepuluan Banda, Kabupaten Maluku Tengah. Kondisi dari bangunan perk sudah sangat memprihatinkan yaitu hanya tinggal pondasinya saja dan hanya beberapa saja yang dapat dikenali.

Dari penelitian arkeologi di Maluku, secara obyektif akan dapat diungkapkan dan dijelaskan terhadap tahap-tahap budaya yang berkembang di masing-masing wilayah atau daerah yang ada di seluruh Propinsi Maluku, serta persentuhan dan akulturasi budaya pada daerahdaerah disekitarnya. Selain itu pula, dengan penelitian arkeologi akan dapat pula diamati, diungkapkan dan dijelaskan anasir-anasir budaya asing yang diserap dan disesuaikan dengan budaya masyarakat setempat. Kontribusi penelitian arkeologi yang telah dilakukan selama ini di Maluku secara garis besarnya dapat dijelaskan sebagai berikut :

1. Menjelaskan bahwa di Maluku telah berkembang pula budaya prasejarah sebagai ciri dari bentuk budaya regional.

2. Tradisi budaya prasejarah di beberapa tempat di Maluku sampai sekarang masih berkembang, utamanya dolmen 
yang dapat dipadukan dengan bentuk budaya lokal yang berkembang belakangan.

3. Terjadinya proses persentuhan budaya daerah dengan tradisi besar yaitu Islam dan Eropa.

\subsection{Pemahaman Nilai Budaya Masa Lampau}

Dalam proses pembangunan yang semakin cepat perubahan dan dinamikanya, arkeologi memandang bahwa upaya-upaya pembinaan dan pengembangan kebudayaan harus mampu memberikan makna yang dalam, artinya bahwa dalam rangka melestarikan, mengembangkan dan memasyarakatkan tinggalan budaya masa lampau harus dapat memberikan pandangan yang luas terhadap nilai budaya masa lampau baik secara individu maupun kelompok-kelompok masyarakat dalam upaya mengenal jati diri dan memperkokoh jiwa persatuan dan kesatuan.

Berkenaan dengan hal tersebut, maka dipandang perlu untuk melakukan penelitian dan pengakajian suatu tinggalan budaya masa lampau secara cermat, dengan menggunakan metode yang memadai, karena hasil budaya tersebut mempunyai suatu nilai yaitu berupa konsepkonsep mengenai segala sesuatu yang dianggap berharga dan penting oleh setiap individu atau kelompok masyarakat sehingga dapat berfungsi sebagai pedoman orientasi dalam menjalani kehidupan masing-masing baik disetiap individu maupun dalam kelompok-kelompok masyarakat. Selain itu pula nilai budaya juga merupakan sesuatu yang ideal, suatu paradigma yang menyatakan realita sosial yang diinginkan dan dihormati.

Lebih jauh dijelaskan bahwa nilai budaya terdiri dari kata nilai dan budaya. Nilai dapat diartikan sebagai konsep abstrak yang dapat hidup dalam alam pikiran masyarakat mengenai apa yang dianggap penting dan berharga dalam kehidupan. Sedangkan budaya adalah merupakan daya dan budi berupa cipta, rasa dan karsa. Jadi nilai budaya dapat diartikan sebagai aspek ideal yang terwujud sebagai konsep-konsep abstrak yang hidup dalam pikiran sebagian besar dari masyarakat mengenai apa yang dianggap penting dan berharga. Nilai budaya itu mengandung aspek perhatian, minat, kesenangan, keinginan, kebutuhan, harapan, rangsangan, dan berbagai peraturan yang menjadi kerangka acuan dalam menentukan sikap dan tindakan manusia. Dengan demikian nilai budaya tidak langsung dapat dipegang atau terlihat akan tetapi hal itu tercermin dalam pola tingkah laku normatif yang berada dalam pikiran masyarakt pendukung dari tinggalan budaya tersebut. Pemahaman terhadap nilai dari suatu tinggalan budaya akan dapat mempermudah dalam upaya mensosialisasikannya, karena memasyarakatkan tinggalan budaya masa lampau berarti memperkenalkan nilai budaya yang selama ini belum dikenali. Upaya ini salah satunya dapat dilakukan dengan mengadakan penelitian yang baik dan benar. Dalam hal ini arkeologi merupakan salah satu bidang ilmu yang mempelajari tentang kebudayaan masa lampau melalui tinggalan budaya materialnya sangat tepat dan mempunyai peranan yang penting dalam mengkaji, menjelaskan, dan menyebarluaskan hasil-hasil tinggalan budaya tersebut dan nilai luhur yang dikandungnya kepada masyarakat luas. Hal ini didukung pula oleh tiga tujuan utama dari penelitian arkeologi yaitu; (1) menggambarkan sejarah kebudayaan; (2) merekonstruksi cara hidup manusia di masa lampau; dan (3) menjelaskan proses transformasi budaya yang telah berlangsung. Selain dengan mengadakan penelitian arkeologi sosialisasi nilai budaya masa lampau dalam hal ini juga dapat dilakukan dengan education cultural yaitu melalui seminar-seminar, ceramah-ceramah, pameran dan penyebarluasan hasil-hasil penelitian di berbagai lapisan masyarakat.

\section{Penutup}

Pengetahuan tentang arkeologi sebagai salah satu bidang ilmu di Maluku dapat dikatakan masih kurang, sehingga masyarakat Maluku belum banyak mengetahui secara luas tentang sasaran yang hendak dicapai dari ilmu arkeologi tersebut. Meskipun demikian arkeologi di Maluku baik sebelum maupun sesudah berdirinya Balai Arkeologi Ambon sudah ikut berpartisipasi dalam upaya mengungkapkan dan memperkenalkan tinggalan budaya masa lampau yang selama ini belum diketahui baik bentuk, fungsi dan nilai yang terkandung di dalamnya.

Penelitian arkeologi di Maluku selama ini sudah dapat memberikan gambaran awal tentang potensi kepurbakalaan yang terkandung dibeberapa wilayah/daerah di Maluku. Kepurbakalaan yang dimaksud tersebut di antaranya adalah menhir, dolmen atau meja batu, keramik lokal, pagar batu, altar batu, lukisan-lukisan (gua, dinding batu karang), pemukul kulit kayu dan lain sebagainya. yang mewakili 
jaman prasejarah. Tinggalan arkeologi lainnya seperti kedaton, mesjid, makam, naskah dan lain sebagainya yang mewakili jaman Islam.

DAFTAR PUSTAKA

Tinggalan yang mewakili jaman kolonial adalah berupa benteng, gereja, perk dan lain sebagainya. Selain itu pula penelitian arkeolog juga telah dapat memberikan pandangan yang lebih luas tentang bentuk atau hasil-hasil budaya masa lampau yang harus dijaga, dipelihara dan dilestarikan sehingga nantinya warisan para lelehur tersebut masih dapat dinikmati/diketahui oleh generasi yang akan datang.

Penelitian arkeologi selain dapat menampilkan hasil kebudayaan dalam wujud fisik, juga diharapkan mampu memberikan pendalaman terhadap pemahaman nilai budaya yang terkandung dalam setiap tinggalan budaya masa lampau itu sendiri. Karena secara keseluruhan bahwa kebudayaan itu pada hakekatnya adalah suatu abstraksi atau generalisasi dari prilaku individu-individu. Dilain pihak individuindividu tersebut adalah merupakan totalitas dari suatu masyarakat atau suatu bangsa. Individu dan kebudayaan atau sebaliknya kebudayaan dan individu memiliki keterkaitan yang erat, maka secara psikologis ada keterkaitan yang erat pula antara kebudayaan dan kepribadian. Dengan demikian dapatlah dikatakan bahwa kepribadian bangsa sangatlah erat kaitannya dengan kebudayaan bangsa.

Sehubungan dengan hal tersebut maka pemahaman dan pengamalan terhadap nilai-nilai luhur yang terkandung dari setiap hasil budaya khususnyatinggalan budaya masa lampau perlu ditingkatkan baik dari segi kuantitas maupun kualitas. Sehingga pada akhirnya tujuan yang hendak dicapai yaitu ; menyelamatkan tinggalan budaya masa lampau, menjaga ketahanan kebudayaan nasional, membina persatuan dan kesatuan bangsa, dan memperkokoh jati diri dan kepribadian bangsa serta memupuk rasa kebanggaan nasional khususnya di kalangan masyarakat Maluku dan seluruh bangsa Indonesia pada umumnya dapat ditingkatkan. Diyakini pula bahwa kesadaran akan jati diri banyak dipengaruhi oleh pengetahuan tentang masa lalu, sehingga jiwa kebangsaan itu pada masa kini dan dapat bertahan pada ciri khasnya sebagai bangsa yang tetap berpijak pada landasan falsafah dan budayanya sendiri.

Abdurracham Paramita R, 1973,

Bunga Rampai Sejarah Maluku (1), Lembaga Penelitian Sejarah Maluku, Jakarta.

Rijoli Frans, 1994,

Buah Emas Dari Banda, Laporan Survey Pengadaan, Museum Negeri Siwalima.

Hanna A. Willard \& Des Alwi, 1996,

Ternate dan Tidore Masa Lalu Penuh Gejolak, Pusat Sinar Harapan, Jakarta.

Heekeren, H.R. van, 1972,

The Stone Age of Indonesia, The Hague Martinus Nijhoff.

Intan S. Fadhlan M. dan Istari Rita T.M, 1996,

Geologi dan Arkeologi Situs Gua Kei Kecil, Maluku Tenggara, Propinsi Maluku, Laporan Penelitian Arkeologi. Pusat Penelitian Arkeologi Nasional, Bagian Proyek Penelitian Purbakala Maluku.

Maiola J, 1977, Glance at the Moluccas.

Pattikayhatu J. A, 1993,

Sejarah Daerah Maluku, Departemen Pendidikan dan Kebudayaan

Pattikayhatu J. A, 1994,

Sejarah Daerah Tematis Zaman Kebangkitan Nasional di Daerah

Maluku (1900-1942), Departemen Pendidikan dan Kebudayaan. 
Soegondho, S, 1996

Penelitian Kepurbakalaan Desa Aboru, Kecamatan Pulau Haruku, Maluku Tengah, Pusat Penelitian Arkeologi Nasional, Bagian Proyek Penelitian Purbakala Maluku.

Soejono, R.P, dkk 1994,

Sejarah Nasional Indonesia I. PN Balai Pustaka, Jakarta.

Sukendar, H, 1982,

Megalitik di Nias. Analisis Kebudayaan Nomor 2, Departemen Pendidikan dan Kebudayaan, Jakarta.

Syaranamual, 1997

Sejarah Kerajaan Iha, Laporan Penelitian. Departemen Pendidikan dan Kebudayaan, Direktur Jenderal Kebudayaan, Balai Kajian Sejarah dan Nilai Tradisional Maluku dan Maluku Utara

Tim Penelitian., 1996

Survey Arkeologi Islam di Ternate dan Tidore, Laporan Penelitian Arkeologi. Propinsi Maluku, Pusat Penelitian Arkeologi Nasional, Proyek Penelitian Purbakala Maluku. 